\title{
Designing and Sensitivity Analysis of an Off-Grid Hybrid Wind-Solar Power Plant with Diesel Generator and Battery Backup for the Rural Area in Iran
}

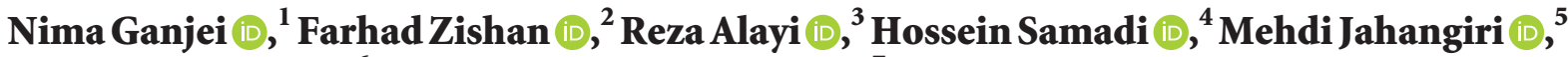 \\ Ravinder Kumar $\mathbb{B}^{6},{ }^{6}$ and Amir Mohammadian $\left(\mathbb{D}^{7}\right.$ \\ ${ }^{1}$ Department of Electrical Engineering, Science and Research Branch, Islamic Azad University, Tehran, Iran \\ ${ }^{2}$ Department of Electrical Engineering, Sahand University of Technology, Tabriz, Iran \\ ${ }^{3}$ Department of Mechanics, Germi Branch, Islamic Azad University, Germi, Iran \\ ${ }^{4}$ Department of Mechanics, Qazvin Branch, Islamic Azad University, Qazvin, Iran \\ ${ }^{5}$ Department of Mechanical Engineering, Shahrekord Branch, Islamic Azad University, Shahrekord, Iran \\ ${ }^{6}$ Department of Mechanical Engineering, Lovely Professional University, Phagwara Jalandhar 144411, Punjab, India \\ ${ }^{7}$ University of Applied Science and Technology, Tehran, Iran
}

Correspondence should be addressed to Reza Alayi; reza.alayi@yahoo.com

Received 28 September 2021; Revised 4 December 2021; Accepted 19 January 2022; Published 10 February 2022

Academic Editor: Justo Lobato

Copyright (C) 2022 Nima Ganjei et al. This is an open access article distributed under the Creative Commons Attribution License, which permits unrestricted use, distribution, and reproduction in any medium, provided the original work is properly cited.

\begin{abstract}
Because of the lack of transmission and distribution grid of electricity in remote and inaccessible areas due to the high cost of construction of the transmission line along with the unsuitable geographical conditions and taking into account the factors affecting sustainable energy production, renewable energy seems like a sensible solution. Therefore, in this paper, considering the solar and wind potential of Turkalan village located in East Azerbaijan Province, the combined solar-wind-diesel generator system with battery bank and independent of the grid was evaluated. Sensitivity analysis and optimal measurement of the studied system were performed by HOMER software. Sensitivity analysis was performed on the parameters of solar radiation, light reflection from the environment, and wind speed. The goal was to supply $22 \mathrm{kWh} / \mathrm{d}$ of energy with a maximum load demand of $2.5 \mathrm{~kW}$. The four hybrid systems proposed by the software considering the total net present cost (NPC) were solar-generator-battery, solarwind-generator-battery, solar-battery, and solar-wind-battery, respectively. The studies were conducted to determine which of the systems is more suitable for the area.
\end{abstract}

\section{Introduction}

Today, the use of renewable resources is on the agenda of many countries around the world, and an important investment process in the world is being developed in dispersed products. Regarding environmental issues and global warming, the use of these renewable energies has become necessary in the past [1-3]. By 2016, worldwide electricity generation from fossil fuels and renewable resources is $75.5 \%$ and $24.5 \%$, respectively, of which energy produced by countries of China, America, Brazil, Germany, and Canada is superior in this area [4-6]. Renewable energy use is an alternative to fossil power plants due to its easy access and the renewable energy structure, lack of transmission and distribution network in remote areas due to the high cost of construction of the transmission line along with the inadequacy of the geographical conditions, and taking into account the factors affecting the sustainable energy production. The use of an independent grid system is a convenient option to meet the need to use electricity [7-9]. Over the years, researchers have been struggling to address the weakness of renewable resources by concentrating on the use of these resources combined with overcoming the weakness of these resources, making progress on the use of 
these distributed resources independently of the network or connected to the network [10-13]. However, in the design of dispersed production systems, it has combined challenges such as energy management, due to the intermittent nature of renewable resources and the diversification of energy demand [14-16], but the need for energy at all times of day and meeting consumer needs in mind getting system reliability due to unstable weather conditions in the area during daylight hours is used to store excess energy at times that require reduced energy consumption and the use of this energy when needed by the storage or battery $[17,18]$.

The necessity of acquiring accurate region information and the overall view of the design of the system to meet the demands of the year in hybrid systems is crucial for obtaining optimum size [19]. In this context, software such as HOMER and iHOGA can be used to obtain the optimum size and design of the hybrid system [20, 21]. Homer software is provided by the National Energy Laboratory of the United States to design a variety of microgrid systems, connected to the network, isolated from the network, and access to the climate database, with economic evaluation and analysis of the sensitivity of existing parameters, including energy cost and strategy to meet the load and obtain the lowest final cost of the system; and it proposes an optimal solution system for load balancing [22-24]. The disadvantages of software can be high computational time and not able to optimize multiobjectives [25]. In these articles, a general review is provided using this software for optimal combination programming. Research findings [26] analyze the cost of wind and solar hybrid systems with access to solar and wind resources in a region of Georgia, based on a combination of the independent network of wind and solar power plants and considering the life span of 25 years for the design project. Also in referring [27] has used a $5 \mathrm{~kW}$ microturbine in Nigeria to meet the design needs of the project. Combined systems are typically designed from two or more dispersed generation sources such as biomass, the geothermal, wind, solar, and microturbine water with a backup source for energy access throughout the hours. In the meantime, the use of solar and wind combinations has been of particular interest in many parts of the world [28]. The use of batteries or power grids is for easy access to energy at times when the production of energy from renewable sources due to climate change in the region's climate increases the reliability of the system. In the latest research, hydrogen can be used as a high-efficiency source compared to batteries [29].

The selection of each component of the hybrid power plant considers the climate and geography of the region depending on the needs of the consumer, considering the costs of construction, exploitation, social and environmental costs, and finally options which have the most favorable economic and environmental conditions than other options. In Figure 1, a hybrid system is shown.

The purpose of this study is to find the annual electricity production of the microgrid system and the optimal capacity of system components and compare between different modes. From the types of equipment, the most economical type of combination is selected, and finally, the net profit of the whole system, which is calculated according to the net present cost method, is expressed along with the relevant analyses.

\section{Material and Method}

Accurate information about the geographical environment is very important for analyzing renewable energy systems. Because renewable energy sources are highly dependent on environmental factors, the intensity of sunlight and wind is a function of time. So, the first step in designing production systems based on renewable sources is to determine renewable energy sources. The most important factor in the use of renewable energy is economic parameters; in this study, HOMER software has been used for this work and determination of economic indicators. Figure 2 shows an overview of the system being designed.

The flowchart of software performance is shown in the figure below. The type and number of inputs required to perform simulation, optimization, and economic ranking calculations are shown in the flowchart. Also, technicaleconomic-energy-environmental outputs show the high ability of software to analyze issues related to renewable energy.

2.1. Climatic Conditions of Solar Energy. The sun is a massive source of energy that supplies our power to direct and indirect forms and causes natural processes such as the displacement of the air. The Earth's share of energy from the sun is a small amount of total solar radiation. Solar energy can be one of the most important renewable energies for replacing fossil fuels. As a result, this emerging source has become a priority in many countries, such as China, to increase energy production and greater access [2]. Solar energy is converted into electrical energy by no solar cell [19]. Iran is one of the countries with a good potential to invest in this area in terms of geographical location in terms of sunlight. In this study, the rural Turkalan area located near the city of Ahar in East Azerbaijan Shargi Province has been studied. Using the HOMER software, the amount of sunlight in the region studied is shown in Figures 3 and 4.

In the HOMER software, by specifying the area required by latitude and longitude, the average sunlight according to Figure 3 is introduced with the main index. Sensitivity analysis was performed by entering two different indexes of 4 and $5(\mathrm{kWh} / \mathrm{m} 2 / \mathrm{d})$. Also, in Figure 5, the amount of received sunlight is shown in different months and at different times.

The power produced by solar cells $\left(\mathrm{P}_{\mathrm{PV}}\right)$ is calculated from the following equation by the HOMER software [31]:

$$
P_{P V}=Y_{P V} f_{P V} \frac{\overline{G_{T}}}{\overline{G_{T, S T C}}}
$$

where $Y_{p v}$ is the output power of the PV panels in the standard conditions $(\mathrm{kW}), \mathrm{f}_{\mathrm{PV}}$ is the derating factor, $\overline{G_{T}}$ is the solar radiation received to the collector surface $\left(\mathrm{kW} / \mathrm{m}^{2}\right)$, and $\overline{G_{T, S T C}}$ is the value of $\overline{G_{T}}$ in the standard conditions $\left(1 \mathrm{~kW} / \mathrm{m}^{2}\right)$. The angle of the solar cells is equal to the latitude of the studied station [31]. 


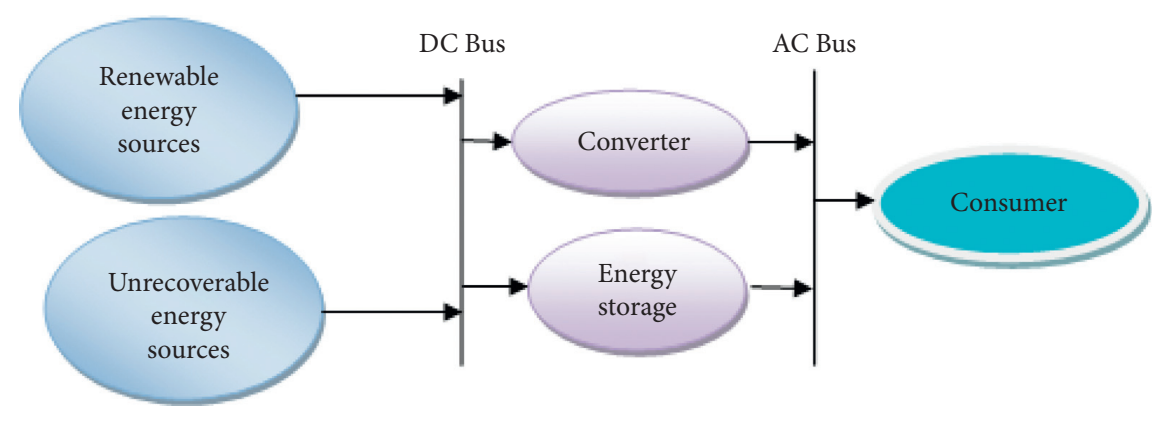

Figure 1: Hybrid system model.

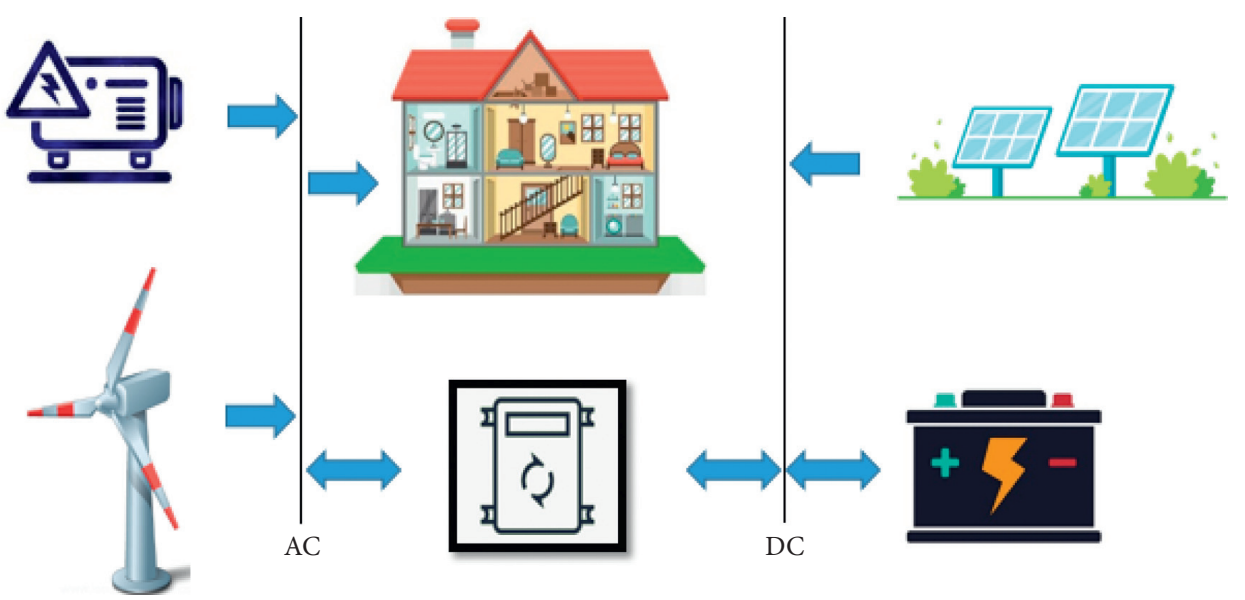

FIGURE 2: Energy systems based on wind turbines and photovoltaic cells.

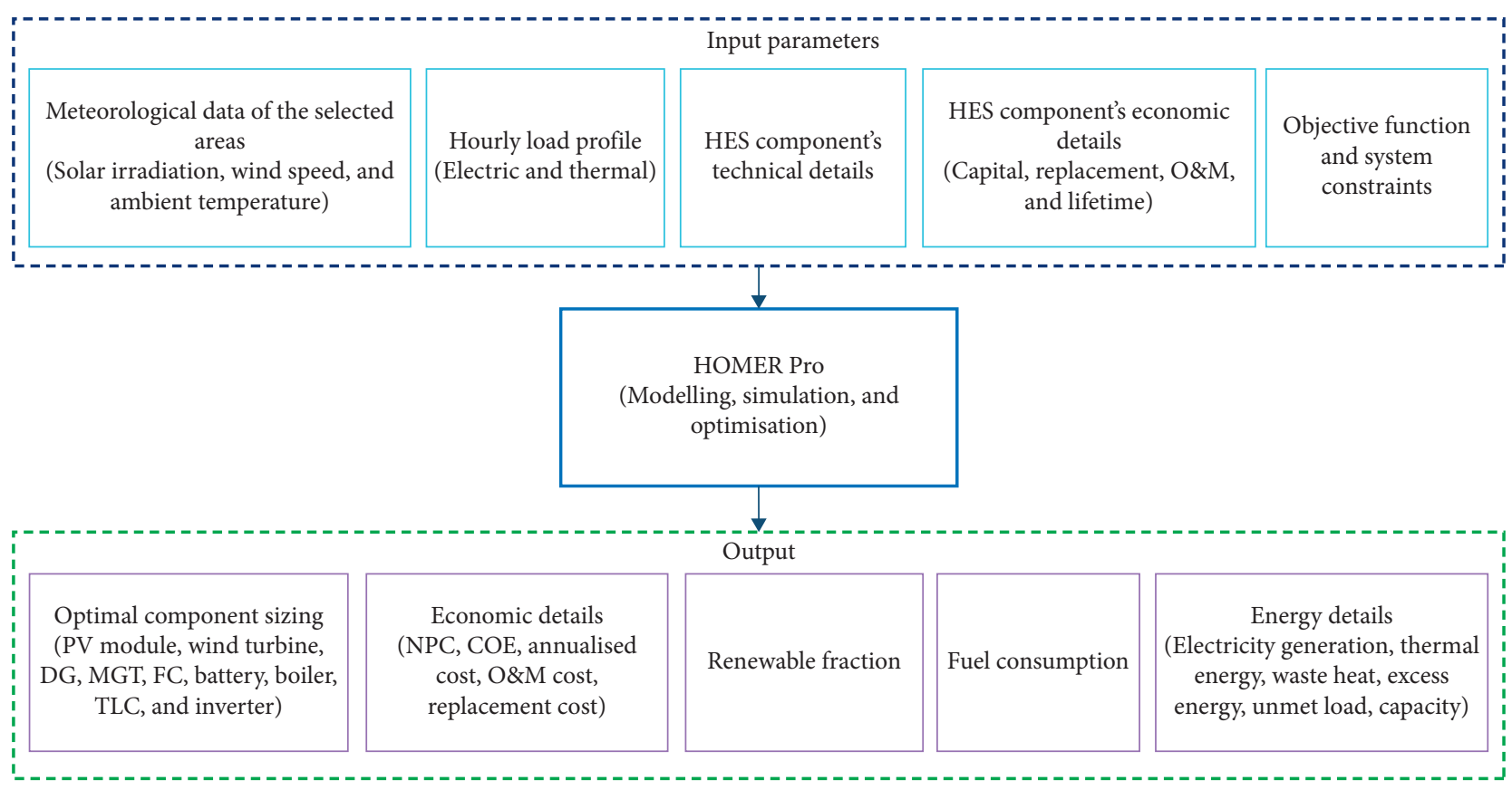

FIGURE 3: Flowchart of HOMER software performance [30].

2.2. Wind Energy. Because of the different rays of the sun in different latitudes, the surface of the rugged terrain causes changes in temperature and pressure, resulting in a wind blowing. Often, the nature of wind energy is oscillating and intermittent and does not have a definite time for constant heat. The disadvantages of wind energy can be attributed to 


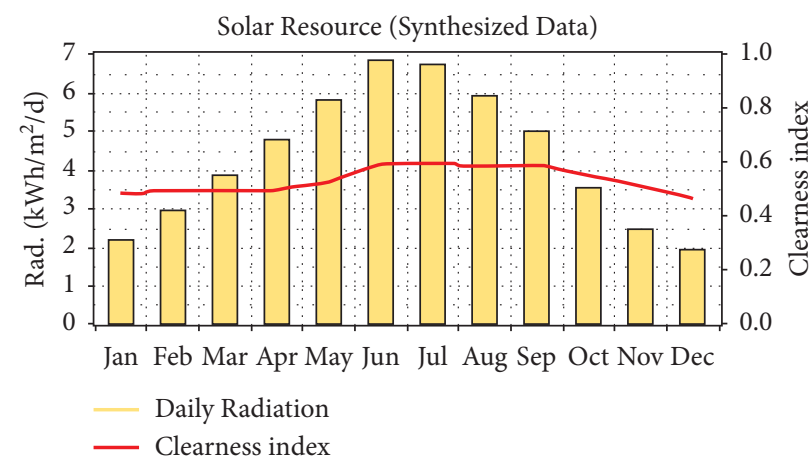

FIgURE 4: The amount of solar radiation in the Turkalan area.
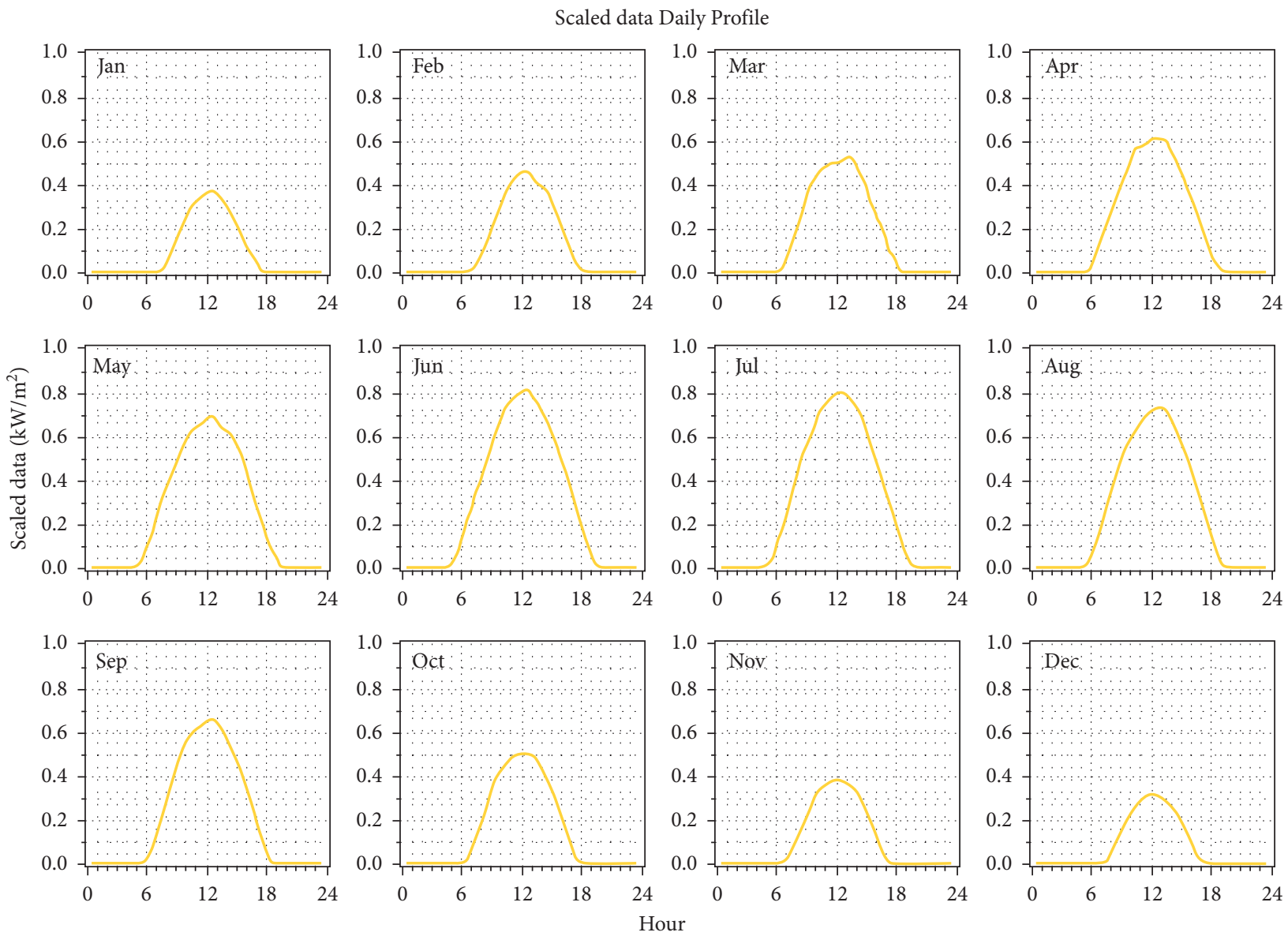

Figure 5: Annual Profile of Sun Radiation in the Turkalan Area $\left(\mathrm{kW} / \mathrm{m}^{2}\right)$.

the variability of production at different times and low reliability [20]. To obtain the wind speed in the area, using the Meteororm software, wind speed information is obtained according to Figures 6 and 7. Despite environmental factors such as ripples affecting wind speed, various wind speeds of $2.5 \mathrm{~m} / \mathrm{s}$ and 4 were used for the assessment and analysis of sensitivity [32].

The output power of a wind turbine depends on its altitude [33]. The output power of wind turbine is calculated by the following equation by the HOMER software [34]:

$$
P_{W T G}=\frac{\rho}{\rho_{0}} P_{W T G, S T P}
$$

where $\rho$ is the air density in real conditions, $\rho_{0}$ is the air density in standard conditions, and $\mathrm{P}_{\text {WTG, STP }}$ is the output power $(\mathrm{kW})$ which is obtained from the turbine power curve.

Wind turbines are used to generate electricity, while small wind turbines have been used to save costs. These types of turbines have low-diameter rotors, which are intended here on the consumer side to charge the batteries. The cost of 

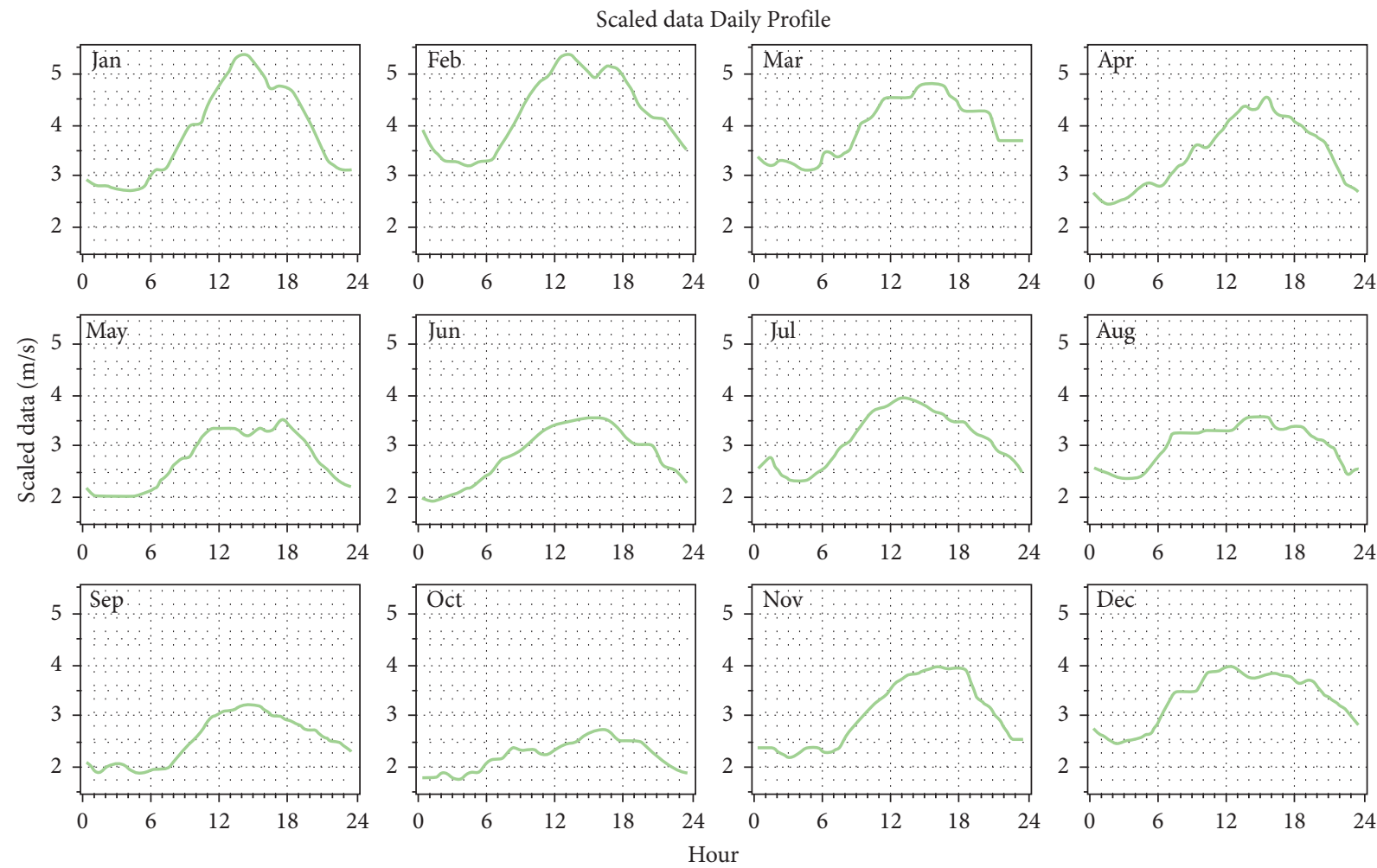

FIgURE 6: Wind profile in different months in the Turkalan area.

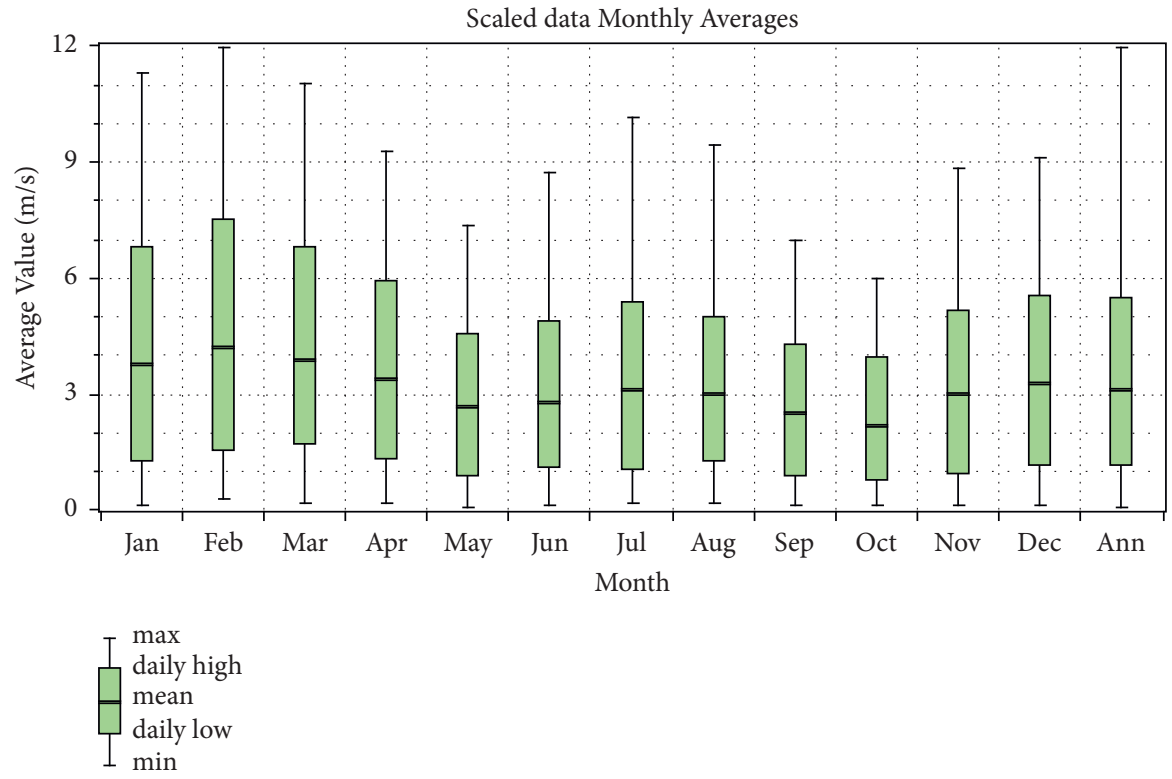

Figure 7: Wind speed in different months in the Turkalan area.

a one-kilowatt turbine with a life span is 1,200 \$, the cost of replacement and repairs and maintenance for the year is 770 $\$$ and $10 \$ / y r$, respectively, and the production characteristic curve is shown in Figure 8.
2.3. System Configuration, Operation, and Optimization. In this system, photovoltaic unit and wind turbine are present as renewable energy sources, diesel generator as support for power generation, and batteries to store excess 


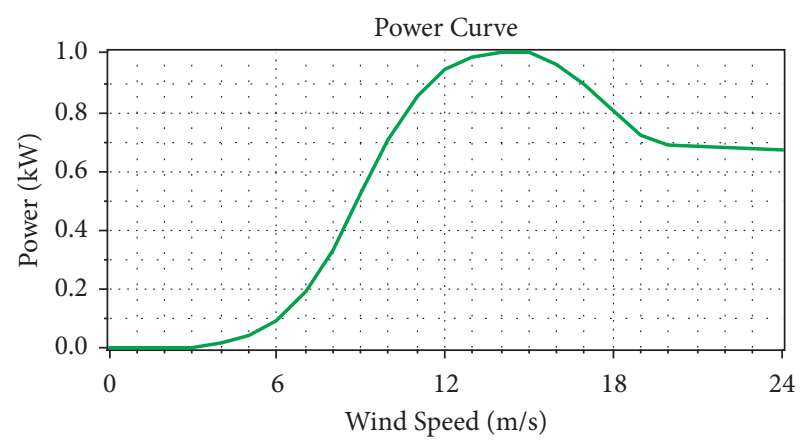

Figure 8: Wind turbine production characteristic curve.

energy and improve system reliability. In some systems, a storage system (battery bank) is used when the power generated by renewable energy sources $\left(\mathrm{P}_{\text {re }}\right)$ at time $t$ is not sufficient to supply the power load $\left(P_{1}\right)$. If the load demand is high and the energy storage system is not able to supply this total energy, the diesel generator intervenes to meet the remaining load demand. This mechanism is based on the following three steps:

(1) First step: If it is $P_{\mathrm{rs}}(t)<P_{1}(t)$, the third step should be done. Otherwise, the second step is done.

(2) Second step: Set the battery bank charge to $t=t+1$ and then perform the first step.

(3) Discharge the battery bank. If it is $\mathrm{SOC}<\mathrm{SOC}_{\min }$, the diesel generator will start; otherwise, the time will be set to $t=t+1$ and then the first step will be done.

The output power of each photovoltaic system $\left(\mathrm{P}_{\mathrm{PV}}\right)$ at moment $t$ can be calculated based on the following relation of solar radiation:

$$
p_{P V}(t)=I(t) \times A \times \eta_{P V} .
$$

In this regard, $I$ is solar radiation, $A$ is the cross section of the photovoltaic system, and $\eta_{P V}$ is the total efficiency of the photovoltaic system panels and the DC/DC converter.

For a wind turbine, if the given wind speed exceeds the cutoff value, the wind turbine will start producing. If the wind speed exceeds the nominal value of the wind turbine speed, the turbine will start producing a constant amount of output power. If the wind speed exceeds the high cutoff value, the wind turbine generator will stop to protect the turbine. The output power of each wind turbine $\left(\mathrm{P}_{\mathrm{WT}}\right)$ at moment $t$ is as follows:

$$
p_{W T}(t)= \begin{cases}0, & v(t) \leq v_{\text {cut-in }} \text { or } v(t) \geq v_{\text {cut }- \text { out }}, \\ P_{r} \frac{v(t)-v_{\text {cut-in }}}{v_{r}-v_{\text {cut }-o<\tau}}, & v_{\text {cut-in }} \leq v(t) \leq v_{r} \\ P_{r}, & v_{r}<V(t)<v_{\text {cut-out }} .\end{cases}
$$

In this regard, $v$ is wind speed, $P_{r}$ is nominal wind turbine powers, $v_{\text {cut-in }}$ is low wind turbine cutoff speeds, $v_{\text {cut- }}$ out is high wind turbine cutoff speeds, and $v_{r}$ is nominal wind turbine speeds.

As a backup power system, the diesel generator will start operating when the power output is insufficient and the power level of the energy storage system is low. In this case, the diesel generator starts working and compensates for the power shortage.

Diesel generator Cons $_{D}=(1 / h)$ fuel consumption depends on the output power and is defined as follows:

$$
\text { Cons }_{D}=B_{D} \times P_{N}^{D}+A_{D} \times P_{D}
$$

In this regard, $P_{N}^{D}$ is the nominal power, $P_{D}$ is the output power of the diesel generator, and two are the parameters $\mathrm{BD}$ and $\mathrm{AD}$ of the fuel curve coefficients, which are defined as $\mathrm{BD}=0.0845(\mathrm{l} / \mathrm{kWh})$ and $\mathrm{AD}=0.246(\mathrm{l} / \mathrm{kWh})$. follows:

The hourly cost of fuel consumption can be obtained as

$$
C_{f}=P_{f u e l} \times \text { Cons }_{D},
$$

$P_{\text {fuel }}$ is the cost of fuel.

Due to the variable behavior of photovoltaic panels and wind turbines, the capacity of the battery bank in the hybrid system is constantly changing. On some systems, the battery charge mode can be achieved as follows:

When the output power of photovoltaic panels and wind generators exceeds the load energy, the battery bank will be in the charging position.

$$
E_{\text {Batt }}(t)=E_{\text {Batt }}(t-1) \times(1-\sigma)+\left[\left(E_{P V}(t)+\left(E_{W t}(t)\right)-\frac{E_{\text {load }}}{\eta_{\text {Inv }}}\right)\right] \times \eta_{\text {Batt }} .
$$

$\mathrm{E}_{\mathrm{Batt}}(t)$ and $\mathrm{E}_{\mathrm{Batt}}(t-1)$ are the amount of battery charge in moments $t$ and $\mathrm{t}-1$, respectively, $\sigma$ hourly self-discharge rate, $\eta_{\text {Inv }}$ inverter efficiencies, $\mathrm{E}_{\text {load }}$ load demand, and $\eta_{\text {Batt }}$ battery bank charge efficiencies.

2.4. Other Equipment and Financial Calculation. The battery in order to save energy and deliver the energy required in different situations, the battery bank in the system is considered. Regarding the types of models available in the software, the vision model 6FM200D with characteristic (200 Ampere, 12V, $917 \mathrm{kWh}$ ) is reviewed at HOMER. The cost of the used battery is $287 \$$, and the replacement and maintenance costs are $266 \$$ and 1 \$/yr, respectively.

For limited use of diesel generators, increasing fuel costs and limiting the supply of diesel fuel, it is therefore emphasized that renewable energy can be used as much as possible. The generator price in this analysis is $164 \$ / \mathrm{kW}$, 
and replacement and maintenance costs are 131 \$ and 0.001 $\$ /$ hr, respectively.

Converter power is needed to communicate between the consumer and the power generator. For a $1 \mathrm{~kW}$ system with $90 \%$ efficiency and a life span of 15 years, the cost of installation and replacement is 300 \$ and 249 \$, respectively. The intended consumer in this design is considered the domestic load of $22 \mathrm{kWh} / \mathrm{d}$ with a maximum load power requirement of $2.5 \mathrm{~kW}$.

$$
\eta_{\text {gen }}=\frac{3.6 P_{\text {gen }}}{\dot{m}_{\text {fuel }} L H V_{\text {fuel }}},
$$

where $\mathrm{P}_{\mathrm{gen}}$ is the total electricity produced by generator $(\mathrm{kWh} / \mathrm{y}), \dot{m}_{\text {fuel }}$ is the total fuel consumption $(\mathrm{kg} / \mathrm{y})$, and $\mathrm{LHV}_{\text {fuel }}$ is the low heating value of the fuel $(\mathrm{MJ} / \mathrm{kg})$.

The generator efficiency is calculated by the following equation by HOMER software [35].

HOMER software presents a list of classified systems based on the total NPC which is calculated by the following equation [36]:

$$
N P C=\frac{C_{\text {ann,total }}}{C R F\left(i, R_{\text {proj }}\right)},
$$

where $C_{\text {ann, total }}$ is the total annual cost (\$), CRF is the capital recovery factor, $i$ is the real interest rate, and $R_{\text {proj }}$ is the project lifetime. The CRF that represents the capital return in $N$ years is calculated by the following equation [37]:

$$
\begin{aligned}
C R F & =\frac{i(1+i)^{N}}{(1+i)^{N}-1} \\
i & =\frac{i^{\prime}-f}{1+f} .
\end{aligned}
$$

The COE in terms of $\$ / \mathrm{kWh}$ during the project lifetime is also calculated by the following equation [38]:

$$
C O E=\frac{C_{\text {ann,total }}}{E_{\text {Load Served }}},
$$

where $E_{\text {Load }}$ Served is the actual electrical charge by the hybrid systems in $\mathrm{kWh} / \mathrm{y}$ that is priced in dollars.

2.5. Limitations. For photovoltaic-wind-diesel generatorbattery system, the following conditions must be met:

$$
\begin{gathered}
N_{\text {wind }}=\text { Integer, } 0 \leq N_{\text {Wind }} \leq N_{\text {Wind }}^{\max }, \\
N_{P V}=\text { Integer, } 0 \leq N_{P V} \leq N_{P V}^{\max }, \\
N_{\text {Batt }}=\text { Integer, } 0 \leq N_{\text {Batt }} \leq N_{\text {Batt }}^{\max },
\end{gathered}
$$

In these relationships, $N_{P V}^{\max }, N_{\text {Wind }}$, and $N_{\text {Batt }}$, respectively, are the most available amount of photovoltaic panels, wind turbines, and batteries.

Limitations for battery model:

Initial battery power SOCintial:

$$
s o c_{t}=s o c_{\text {initial }} .
$$

Minimum and maximum energy stored in the battery:

$$
\begin{aligned}
& s o c_{t} \leq s o c_{\max }, \\
& s o c_{t} \geq s o c_{\min } .
\end{aligned}
$$

Minimum and maximum battery charge capacity:

$$
\begin{aligned}
& P_{t}^{\text {charge }} \leq P_{\text {charge }}^{\max } * U_{t}^{\text {charge }}, \\
& P_{t}^{\text {charge }} \geq P_{\text {charge }}^{\max } * U_{t}^{\text {charge }} .
\end{aligned}
$$

Minimum and maximum battery discharge capacity:

$$
\begin{aligned}
& P_{t}^{\text {discharge }} \leq P_{\text {charge }}^{\max } * U_{t}^{\text {discharge }}, \\
& P_{\mathrm{t}}^{\text {discharge }} \geq P_{\text {charge }}^{\max } * U_{t}^{\text {discharge }} .
\end{aligned}
$$
time:

The battery cannot be charged or discharged at the same

$$
U_{t}^{\text {discharge }}+U_{t}^{\text {discharge }} \leq 1 .
$$

Power at any time for the battery:

$$
s o c_{t}=s o c_{t-1}+\eta_{\text {charge }}^{B} * P_{t}^{\text {charge }}-\frac{P_{t}^{\text {discharge }}}{\eta_{\text {discharge }}^{B}} .
$$

Minimum and maximum diesel power:

$$
\begin{aligned}
& P_{t}^{D} \leq P_{D}^{\max } * U_{t}^{D}, \\
& P_{t}^{D} \geq P_{D}^{\max } * U_{t}^{D}
\end{aligned}
$$

\section{Results}

In Table 1, the cost of the applicable systems along with the optimal equipment sizes is shown by taking into account the analysis of various parameters. The four proposed hybrid systems by the software, taking into account the NPC, are, respectively, solar-generator-battery, solar-wind-generatorbattery, solar-battery, and solar-wind-battery. The three wind speed parameters, the amount of sunlight, and the reflection of light from the surface in this analysis have been used as sensitivity variables. To find the optimal HOMER software system, among the various combinations and layouts of the system in the software search space, with an analysis of 8760 hours, all of the possible scenarios for the system are simulated with respect to the required electrical charge, and all the impossible situations deleted to categorize according to the NPC. The optimization results presented in Figures 9-11 give the high potential of using sunlight and relatively low wind speed, and the region of analysis of the amount of sunlight relative to the constant of the other variables. It is possible to use more solar power in different radiation levels around the area in question. According to Table 1, the sensitivity analysis of the system results from the proposal of two systems with accurate weather data, which is the difference between the two systems in the amount of light reflected from the environment. Because of the 
TABle 1: The effect of changing the intensity of sunlight and wind on the optimal values of the designed system.

\begin{tabular}{|c|c|c|c|c|c|c|c|c|c|}
\hline $\begin{array}{l}\text { Sunlight } \\
\left(\mathbf{k W h} / \mathbf{m}^{2} / \mathbf{d}\right)\end{array}$ & $\begin{array}{l}\text { Wind } \\
\text { speed } \\
(\mathrm{m} / \mathrm{s})\end{array}$ & $\begin{array}{c}\text { Reflects light from } \\
\text { the environment } \\
(\%)\end{array}$ & $\begin{array}{l}\text { Solar } \\
\text { panel } \\
(\mathrm{kW})\end{array}$ & $\begin{array}{l}\text { Wind } \\
\text { turbine } \\
(\mathrm{kW})\end{array}$ & $\begin{array}{c}\text { Diesel } \\
\text { generator } \\
(\mathrm{kW})\end{array}$ & $\begin{array}{c}\text { Battery } \\
200 \\
(\mathrm{Ah})\end{array}$ & $\begin{array}{c}\text { Converter } \\
(\mathrm{kW})\end{array}$ & $\begin{array}{c}\text { Net } \\
\text { present } \\
\text { cost (NPC) }\end{array}$ & $\begin{array}{c}\text { Cost of } \\
\text { generating } \\
\text { energy }(\$ / \mathrm{kWh})\end{array}$ \\
\hline 4.032 & 3.15 & 20 & 13 & 0 & 2 & 17 & 3 & 27020 & 371 \\
\hline 4.032 & 3.15 & 30 & 13 & 0 & 2 & 17 & 3 & 27013 & 371 \\
\hline 4.032 & 2.5 & 20 & 13 & 0 & 2 & 17 & 3 & 27020 & 371 \\
\hline 4.032 & 2.5 & 30 & 13 & 0 & 2 & 17 & 3 & 27013 & 371 \\
\hline 4.032 & 4 & 20 & 8 & 1 & 2 & 22 & 3 & 2342 & 362 \\
\hline 4.032 & 4 & 30 & 8 & 1 & 2 & 22 & 3 & 2338 & 361 \\
\hline 4 & 15.3 & 20 & 14 & 0 & 2 & 17 & 3 & 27597 & 379 \\
\hline 4 & 15.3 & 30 & 14 & 0 & 2 & 17 & 3 & 27588 & 379 \\
\hline 4 & 5.2 & 20 & 14 & 0 & 2 & 17 & 3 & 27597 & 379 \\
\hline 4 & 5.2 & 30 & 14 & 0 & 2 & 17 & 3 & 27588 & 379 \\
\hline 4 & 4 & 20 & 9 & 1 & 2 & 22 & 3 & 2893 & 369 \\
\hline 4 & 4 & 30 & 9 & 1 & 2 & 22 & 3 & 26881 & 369 \\
\hline 5 & 15.3 & 20 & 11 & 0 & 2 & 17 & 3 & 25877 & 355 \\
\hline 5 & 15.3 & 30 & 9 & 0 & 2 & 22 & 3 & 25718 & 353 \\
\hline 5 & 5.2 & 20 & 11 & 0 & 2 & 17 & 3 & 25877 & 355 \\
\hline 5 & 5.2 & 30 & 9 & 0 & 2 & 22 & 3 & 25718 & 353 \\
\hline 5 & 4 & 20 & 8 & 1 & 2 & 17 & 3 & 25383 & 348 \\
\hline 5 & 4 & 30 & 8 & 1 & 2 & 17 & 3 & 25373 & 348 \\
\hline
\end{tabular}

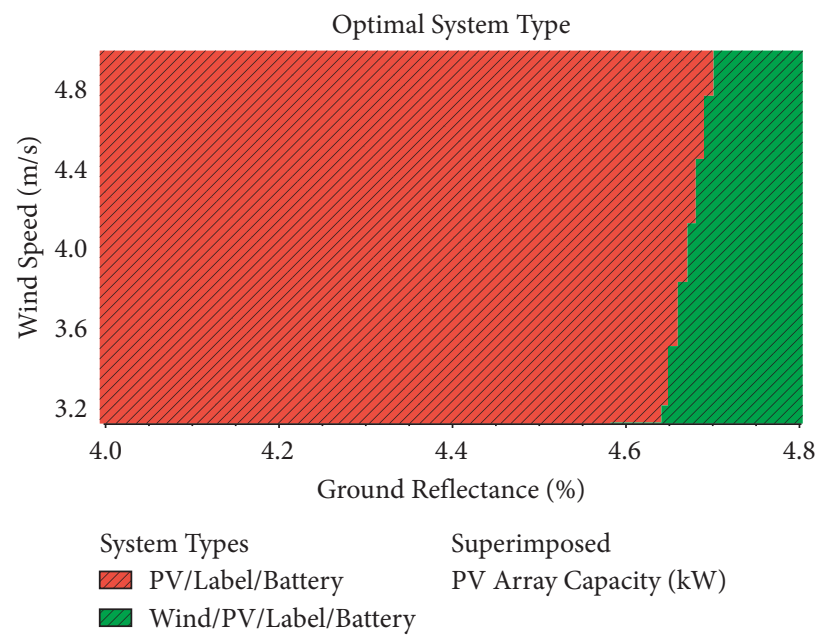

FIgURE 9: Sensitivity analysis for wind velocity variables and reflection level from surface for constant radiation $\left(5 \mathrm{kWh} / \mathrm{m}^{2} / \mathrm{d}\right)$.

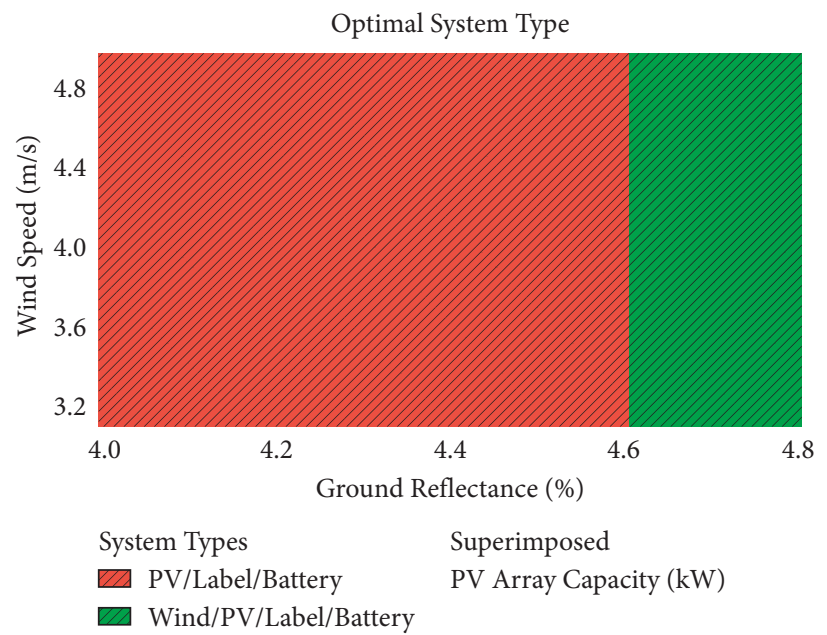

FIGURE 10: Sensitivity analysis for wind speed variables and reflection level from surface for fixed radiation $(32.4 \mathrm{kWh} / \mathrm{m} 2 / \mathrm{d})$. 


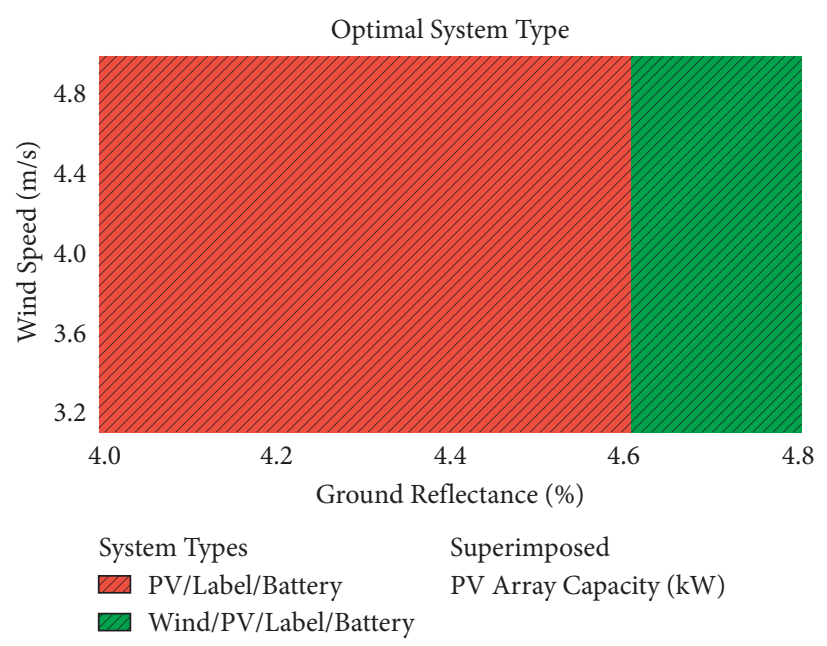

FIGURE 11: Sensitivity analysis for wind speed variables and reflection level from surface for constant radiation $\left(4 \mathrm{kWh} / \mathrm{m}^{2} / \mathrm{d}\right)$.

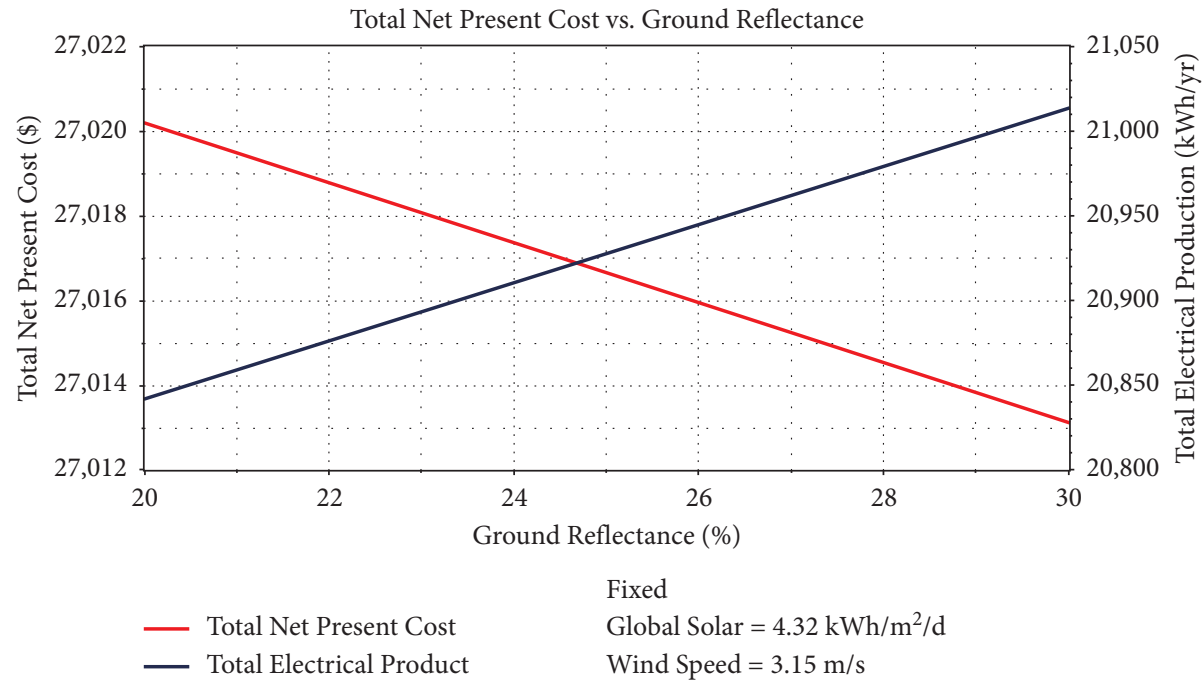

FIGURE 12: Chart of the relationship between the net cost of the system and the system energy production at different percentages of light reflection from the environment.

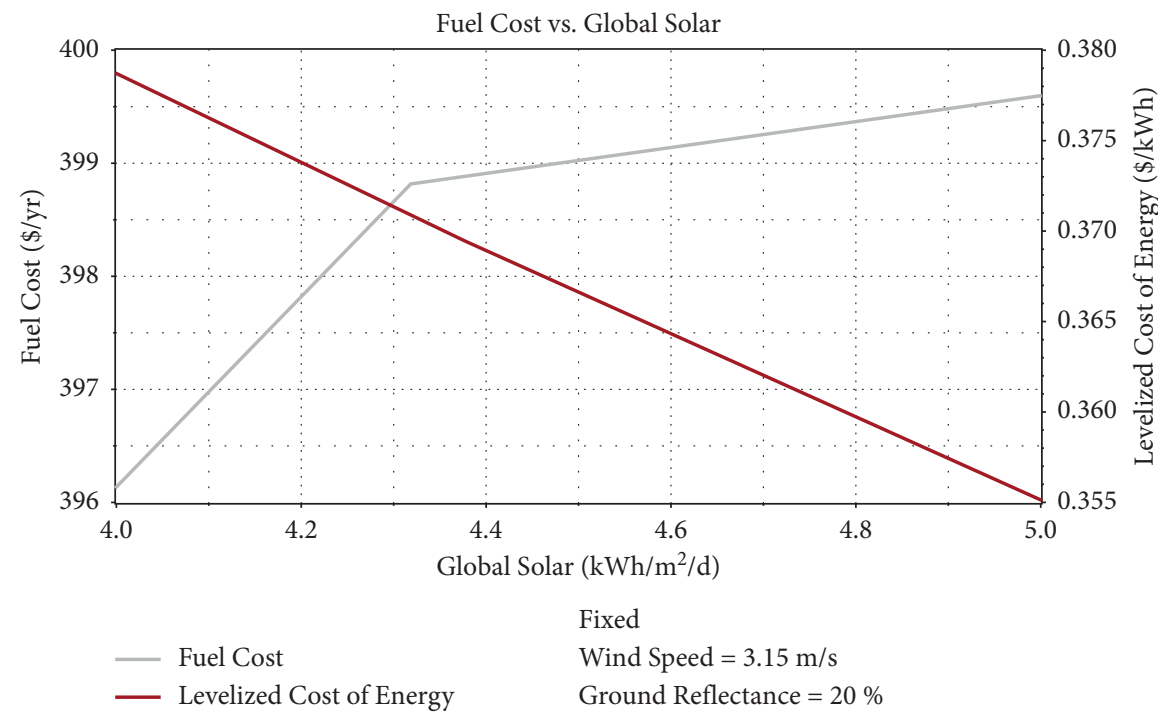

FIGURE 13: Comparison of the cost of diesel fuel with the cost of production by solar panels. 
TABLE 2: Investigation of different scenarios for the studied system.

\begin{tabular}{|c|c|c|c|c|c|c|c|c|c|}
\hline Combined system & $\begin{array}{l}\text { Solar panel } \\
(\mathrm{kW})\end{array}$ & $\begin{array}{l}\text { Wind } \\
\text { turbine }\end{array}$ & $\begin{array}{c}\text { Diesel generator } \\
(\mathrm{kW})\end{array}$ & $\begin{array}{l}\text { Battery } 200 \\
\quad(\mathrm{Ah})\end{array}$ & $\begin{array}{c}\text { Converter } \\
(\mathrm{kW})\end{array}$ & $\begin{array}{c}\text { Initial } \\
\text { capital }(\$)\end{array}$ & $\begin{array}{c}\mathrm{NPC} \\
(\$)\end{array}$ & $\begin{array}{c}\mathrm{COE} /(\$) \\
\mathrm{kWh}\end{array}$ & $\begin{array}{c}\mathrm{CO}_{2} \\
(\mathrm{~kg} / \mathrm{yr})\end{array}$ \\
\hline $\begin{array}{l}\text { Solar-generator- } \\
\text { battery }\end{array}$ & 13 & 0 & 2 & 17 & 3 & 13582 & 27020 & 371 & 2626 \\
\hline $\begin{array}{l}\text { Solar-wind- } \\
\text { generator-battery }\end{array}$ & 10 & 1 & 2 & 22 & 3 & 14492 & 2728 & 379 & 2607 \\
\hline Solar-battery & 14 & 0 & 0 & 50 & 3 & 23900 & 33972 & 536 & 0 \\
\hline Solar-wind-battery & 13 & 1 & 0 & 50 & 3 & 24525 & 34652 & 547 & 0 \\
\hline
\end{tabular}

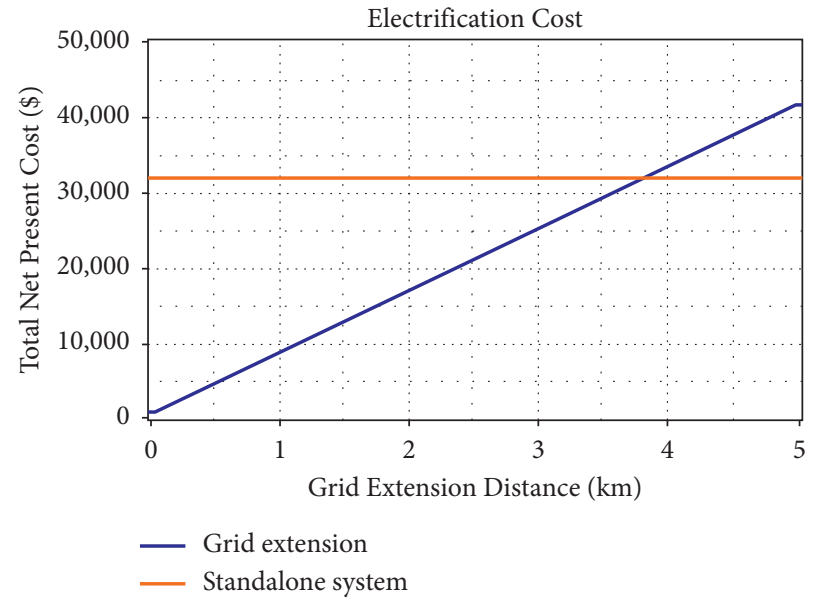

FIGURE 14: Optimization of system execution distance by comparing construction of transmission line.

TABle 3: Optimal specifications of the selected designed system.

\begin{tabular}{lcccccc}
\hline Component & Capital $(\$)$ & Replacement $(\$)$ & O\&M $(\$)$ & Fuel $(\$)$ & Salvage $(\$)$ & Total $(\$)$ \\
\hline PV & 7,475 & 0 & 118 & 0 & 7,593 \\
Generator & 328 & 331 & 61 & 3,620 & -12 \\
Vision 6FM200D & 4,879 & 9,185 & 154 & 0 & -175 \\
Converter & 900 & 179 & 0 & 0 & -23 \\
System & 13,582 & 9,694 & 334 & 3,620 & -210 & 1,043 \\
\hline
\end{tabular}

particular climatic conditions in the area, light reflections are considered in the least conditions. Therefore, the system to run in the area with accurate weather data using a solardiesel combined system with a $20 \%$ light reflection battery is an appropriate option for the implementation of the design at the desired location. Considering the villages around the area that are different from the light and wind speed, one can conclude that by increasing the amount of sunlight, the wind speed, and the amount of light reflected from the environment, the final net cost plus cost of energy production is reduced. With the observations in the precise weather data of the software, Figure 12 shows that increasing the amount of light reflections from the environment on the surface of the solar panels has a positive effect, which increases the amount of energy produced and reduces the net system cost. In Figure 13, for comparison of the cost of diesel fuel with the cost of solar panel production, taking into account the amount of light reflection from the environment of $20 \%$ and wind speed of $15.3 \mathrm{~m} / \mathrm{s}$, it is indicated by the variability of the amount of sunlight by increasing the amount of sunlight, energy costs are much lower than diesel fuel. According to Table 2, the cost of generator fuel is estimated at $4 \$ / \mathrm{L}$. For the photovoltaic/diesel generator system, which is the battery as an energy storage system, NPC for this system is \$ 27020 , to supply energy with this system to $13 \mathrm{~kW}$ for the solar panel, and 17 batteries are needed. In the grid-connected system, the following grid specifications are considered: 2,500\$ per kilometer of transmission line construction, which for this distance is $100 \$$ maintenance costs. In this study, the cost of buying and selling electricity to the grid is estimated at $0.02 \$$. It is economically justified for electricity to run this project at a distance greater than $0.987 \mathrm{~km}$. Figure 14 illustrates the distance between the use of a system independent of the network due to the high cost of construction of transmission lines in difficult areas and out of reach of transmission lines. Table 3 shows the cost of installing, replacing, repairing, and maintaining the system, the cost of fuel, and the cost of the sale of worn-out equipment. As the total cost of the system equipment is $13582 \$$, the replacement is $9694 \$$, and the 


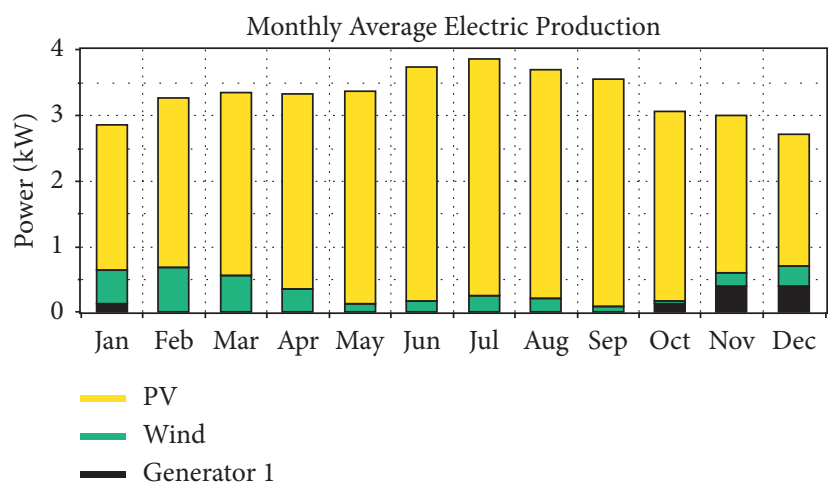

FIgURE 15: Annual energy production chart.

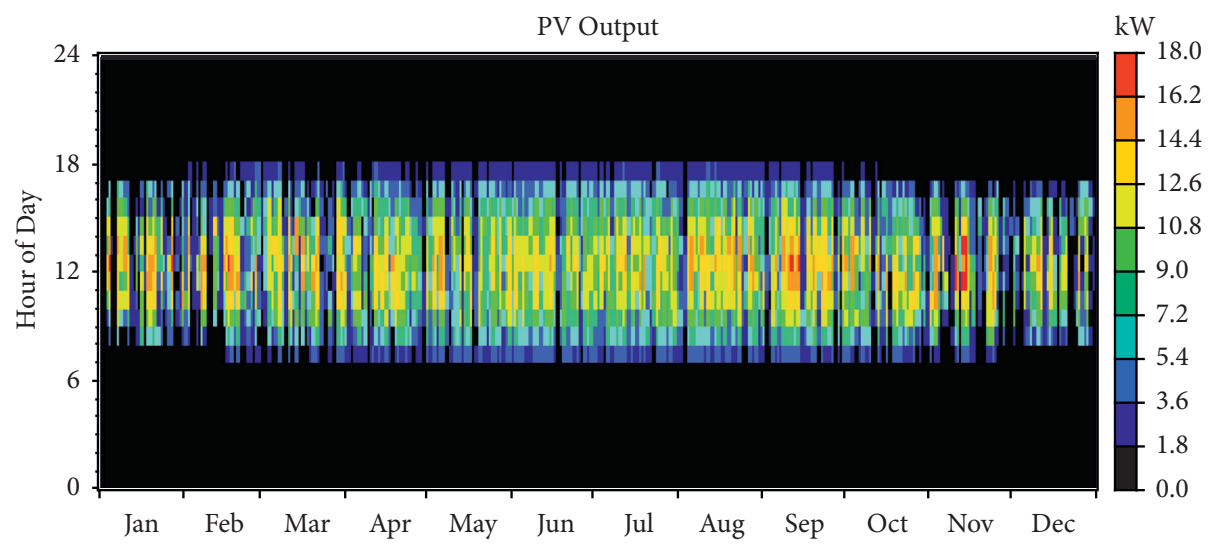

Figure 16: Annual output of solar panel power.

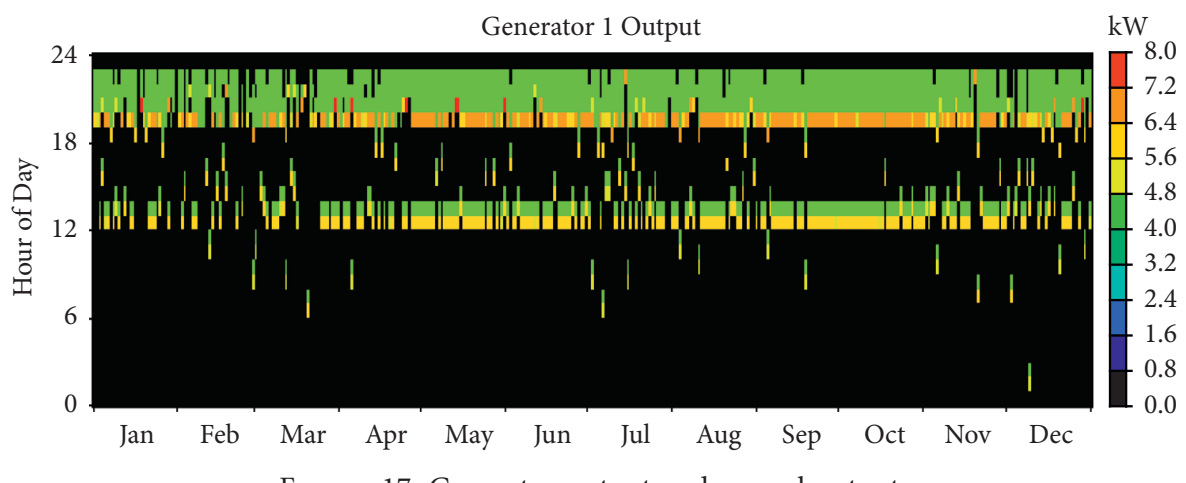

FIGURE 17: Generator output and annual output.

system repairs and maintenance is 334 \$. The amount of energy produced in different months of the year in Figure 15 by solar panels and diesel generators is $89 \%$ and $11 \%$, with a power output of $18587 \mathrm{kWh} / \mathrm{yr}$ and 2260 $\mathrm{kWh} / \mathrm{yr}$, respectively. Figures 16-19 show the output of solar panels and diesel generator at hours of the year. For
Turkalan region, according to the solar radiation and wind speed, four models were defined. Due to the solar radiation of high sunlight and low wind speed, the diesel generator model with photovoltaic cell is more suitable. In this model, the cost of each unit of energy produced is $0.371 \$ / \mathrm{kWh}$, which is much lower than other models. 
PV Array Power Output Daily Profile
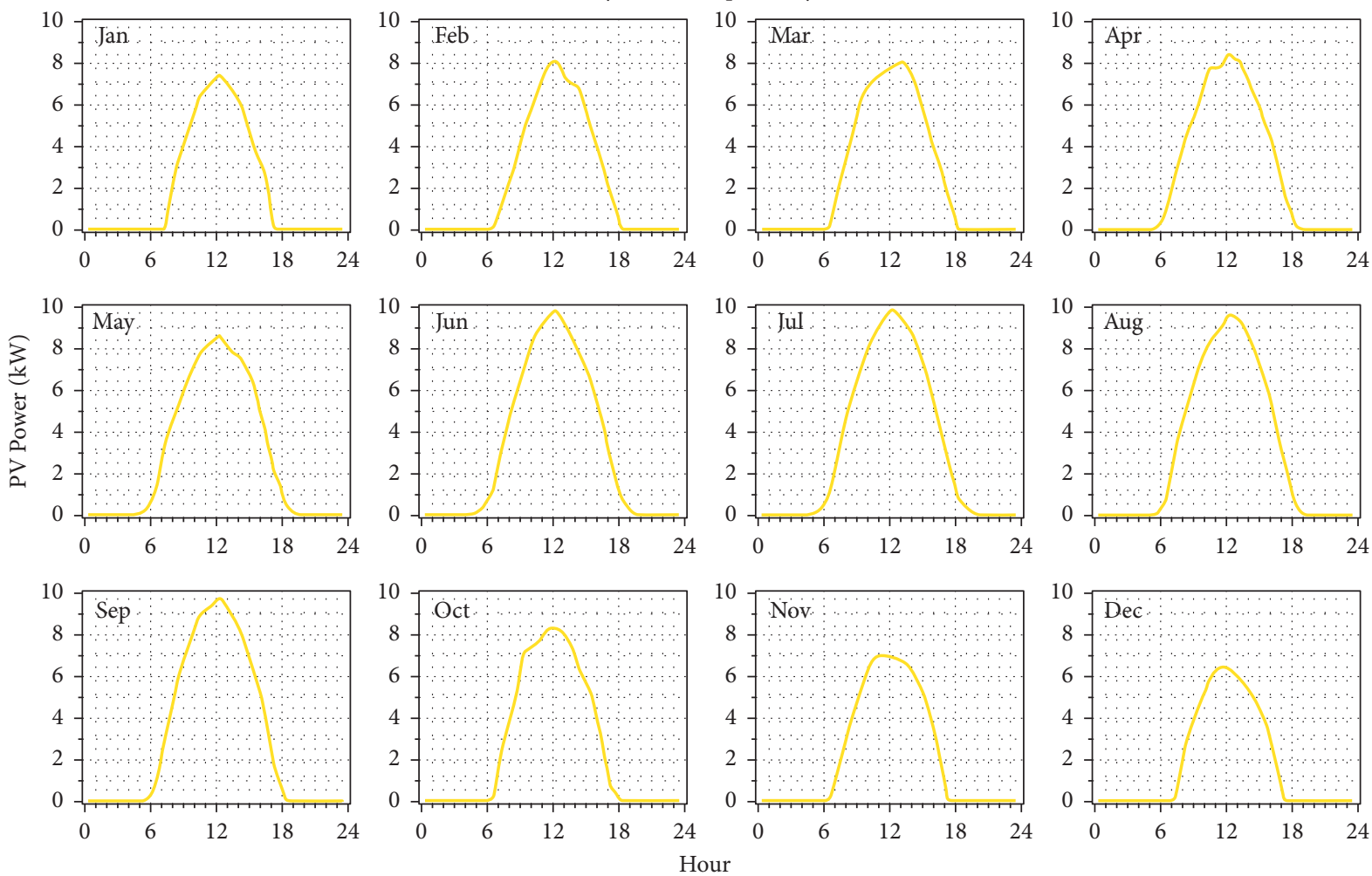

Figure 18: Output of the sun's power by months.
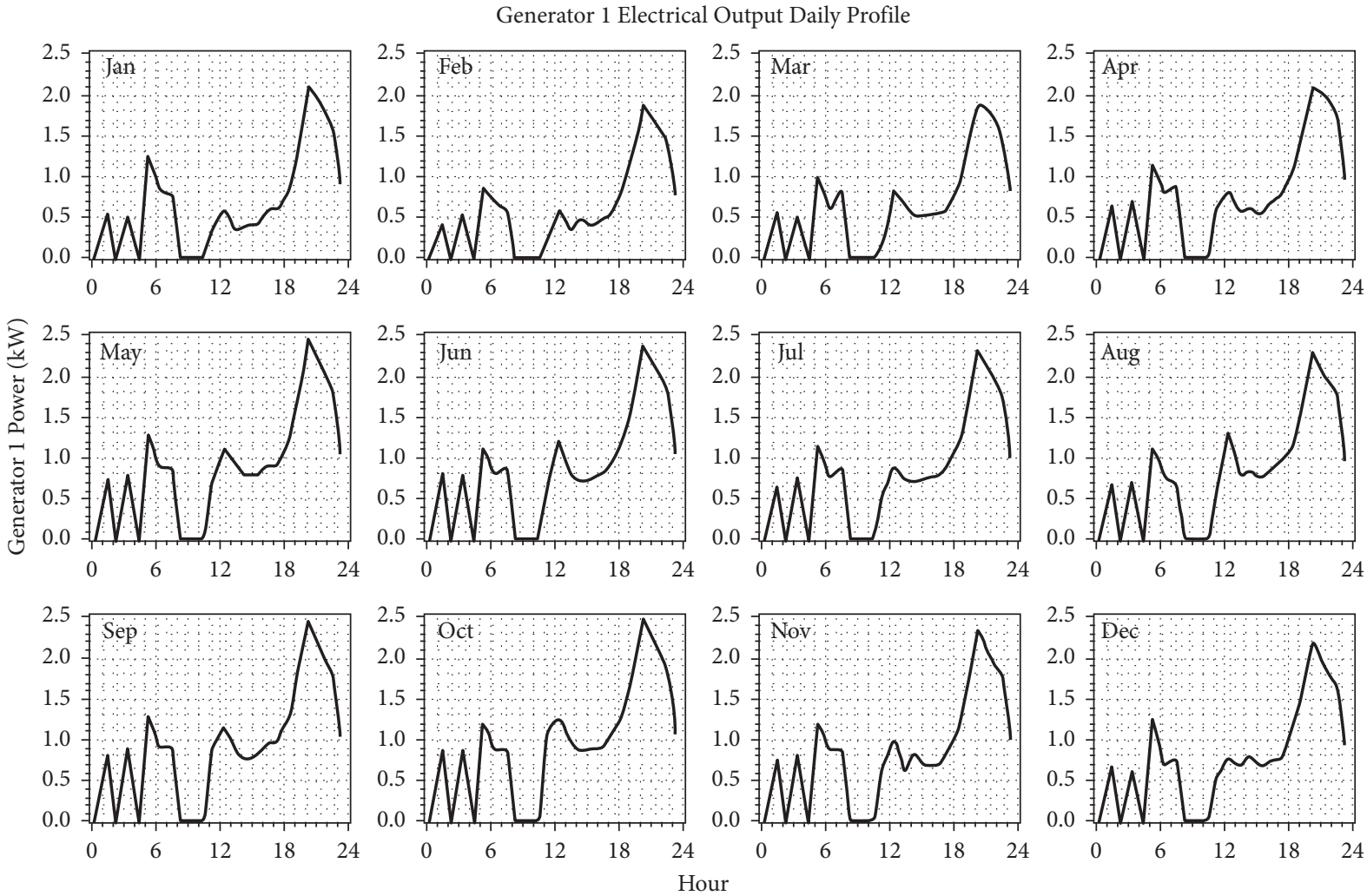

FIgURE 19: Diesel generator power output by month. 


\section{Conclusion}

Due to the lack of energy and the endlessness of renewable energy, new and clean energy has been used in many countries around the world. On the other hand, in remote areas of the grid, independent networks considering the environmental conditions of the region seem to be a sensible solution. Hence, Iran has the potential to use renewable energy as a suitable alternative to fossil fuels. Therefore, in designing the system in HOMER software, the use of hybrid systems has been investigated to improve system reliability and load responses in the Turkalan rural area. In general, due to the increase in the amount of solar radiation, the wind speed, and the reflection coefficient of light from the existing system environment, the net cost is lower than the chosen system. Based on the results obtained from the simulation of the four proposed systems by the software, taking into account the NPC (solar-generator-battery, solar-wind-generator-battery, solar-battery, and solar-wind- battery) with the tests done, the lowest final net cost, respectively, is combined with a solar-generator system with a battery, which has a light reflection coefficient of at least the proportion of other systems at a cost of energy $0.371 \$ / \mathrm{kWh}$, and the amount of energy produced by solar panels and diesel generators is $89 \%$ and $11 \%$, respectively, and the amount of energy is $18587 \mathrm{kWh} / \mathrm{yr}$ and $2260 \mathrm{kWh} / \mathrm{yr}$, respectively, a good solution for supplying the load of the Turkalan area compared to other hybrid systems. The NPC is $3224 \$$ with a capacity of $13 \mathrm{~kW}$ of solar panels and $2 \mathrm{~kW}$ of diesel generator with 17 batteries.

\section{Data Availability}

All data used to support the findings of this study are included in the article.

\section{Conflicts of Interest}

The authors declare that they have no conflicts of interest.

\section{References}

[1] S. A. Abdullahi, F. Folaranmi, A. A. Suleiman, J. O. Mahmud, D. Dania, and M. S. Haruna, "Optimizing the $5 \mathrm{~kW}$ small hydropower supply in mada-gudi community," in Proceedings of the 2017 IEEE AFRICON, pp. 1202-1207, Nassarawa, Nigeria, 2017.

[2] H. Panchal, K. K. Sadasivuni, A. A. A. Ahmed et al., "Graphite powder mixed with black paint on the absorber plate of the solar still to enhance yield: an experimental investigation," Desalination, vol. 520, Article ID 115349, 2021.

[3] M. A. Sina and M. A. Adeel, "Assessment of stand-alone photovoltaic system and mini-grid solar system as solutions to electrification of remote villages in Afghanistan," International Journal of Innovative Research and Scientific Studies, vol. 4, no. 2, pp. 92-99, 2021.

[4] R. Alayi, M. Mohkam, S. R. Seyednouri, M. H. Ahmadi, and M. Sharifpur, "Energy/economic analysis and optimization of on-grid photovoltaic system using CPSO algorithm," Sustainability, vol. 13, no. 22, Article ID 12420, 2021.
[5] R. Alayi, M. H. Ahmadi, A. R. Visei, S. Sharma, and A. Najafi, "Technical and environmental analysis of photovoltaic and solar water heater cogeneration system: a case study of Saveh City," International Journal of Low Carbon Technologies, vol. 16, no. 2, pp. 447-453, 2021.

[6] R. Alayi, R. Kumar, S. R. Seydnouri, M. H. Ahmadi, and A. Issakhov, "Energy, environment and economic analyses of a parabolic trough concentrating photovoltaic/thermal system," International Journal of Low Carbon Technologies, vol. 16, no. 2, pp. 570-576, 2021.

[7] R. Alayi and H. Rouhi, "Techno-economic analysis of electrical energy generation from urban waste in hamadan, Iran," International Journal of Design \& Nature and Ecodynamics, vol. 15, no. 3, pp. 337-341, 2020.

[8] R. Alayi, M. R. Basir Khan, and M. S. G. Mohmammadi, "Feasibility study of grid-connected PV system for peak demand reduction of a residential building in Tehran, Iran," Mathematical Modelling of Engineering Problems, vol. 7, no. 4, pp. 563-567, 2020.

[9] R. Alayi, A. Kasaeian, A. Najafi, and E. Jamali, "Optimization and evaluation of a wind, solar and fuel cell hybrid system in supplying electricity to a remote district in national grid," International Journal of Energy Sector Management, vol. 14, no. 2, pp. 408-418, 2020.

[10] C.-C. Hsu, Y. Zhang, P. Ch, R. Aqdas, S. Chupradit, and A. Nawaz, "A step towards sustainable environment in China: the role of eco-innovation renewable energy and environmental taxes," Journal of Environmental Management, vol. 299, Article ID 113609, 2021.

[11] H. Xiang, P. Ch, M. A. Nawaz, S. Chupradit, A. Fatima, and M. Sadiq, "Integration and economic viability of fueling the future with green hydrogen: an integration of its determinants from renewable economics," International Journal of $\mathrm{Hy}$ drogen Energy, vol. 46, no. 77, pp. 38145-38162, 2021.

[12] S. S. Arefin, "Optimization techniques of islanded hybrid microgrid system-renewable energy - resources," Challenges and Applications, vol. 18, pp. 465-482, 2020.

[13] M. Fatin Ishraque, S. A. Shezan, M. M. Ali, and M. M. Rashid, "Optimization of load dispatch strategies for an islanded microgrid connected with renewable energy sources," Applied Energy, vol. 292, Article ID 116879, 2021.

[14] M. B. Sibuea, S. R. Sibuea, and I. Pratama, "The impact of renewable energy and economic development on environmental quality of ASEAN countries," AgBioforum, vol. 23, no. 1, pp. 12-21, 2021.

[15] U. J. Banday and R. Aneja, "Renewable and non-renewable energy consumption, economic growth and carbon emission in BRICS," International Journal of Energy Sector Management, vol. 14, no. 1, pp. 248-260, 2020.

[16] T. S. Adebayo, H. Rjoub, G. D. Akinsola, and S. D. Oladipupo, "The asymmetric effects of renewable energy consumption and trade openness on carbon emissions in Sweden: new evidence from quantile-on-quantile regression approach," Environmental Science and Pollution Research, vol. 23, pp. 1-12, 2021.

[17] R. Alayi, F. Zishan, M. Mohkam, S. Hoseinzadeh, S. Memon, and D. A. Garcia, "A sustainable energy distribution configuration for microgrids integrated to the national grid using back-to-back converters in a renewable power system," Electronics, vol. 10, no. 15, p. 1826, 2021.

[18] H. Cristian, N. Bizon, and B. Alexandru, "Design of hybrid power systems using HOMER simulator for different renewable energy sources," in Proceedings of the 2017 9th International Conference on Electronics, Computers and 
Artificial Intelligence (ECAI), pp. 1-7, Targoviste, Romania., July 2017.

[19] E. L. V. Eriksson and E. M. Gray, "Optimization and integration of hybrid renewable energy hydrogen fuel cell energy systems - a critical review," Applied Energy, vol. 202, pp. 348-364, 2017.

[20] K. Feng, K. Hubacek, Y. L. Siu, and X. Li, "The energy and water nexus in Chinese electricity production: a hybrid life cycle analysis," Renewable and Sustainable Energy Reviews, vol. 39, pp. 342-355, 2014.

[21] S. A. Shezan, "Feasibility analysis of an islanded hybrid winddiesel-battery microgrid with voltage and power response for offshore Islands," Journal of Cleaner Production, vol. 288, Article ID 125568, 2021.

[22] D. Feroldi, M. Serra, and J. Riera, "Energy management strategies based on efficiency map for fuel cell hybrid vehicles," Journal of Power Sources, vol. 190, no. 2, pp. 387-401, 2009.

[23] D. Feroldi and D. Zumoffen, "Sizing methodology for hybrid systems based on multiple renewable power sources integrated to the energy management strategy," International Journal of Hydrogen Energy, vol. 39, no. 16, pp. 8609-8620, 2014.

[24] S. Ghose, A. El Shahat, and R. J. Haddad, "Wind-solar hybrid power system cost analysis using HOMER for Statesboro, Georgia," SoutheastCon, vol. 23, pp. 1-3, 2017.

[25] A. Kasaeian, A. Shamel, and R. Alayi, "Simulation and economic optimization of wind turbines and photovoltaic hybrid system with storage battery and hydrogen tank (case study the city of Yazd)," Journal of Current Research in Science, vol. 3, no. 5, p. 105, 2015.

[26] C. Li, D. Zhou, H. Wang, Y. Lu, and D. Li, “Techno-economic performance study of stand-alone wind/diesel/battery hybrid system with different battery technologies in the cold region of China," Energy, vol. 192, Article ID 116702, 2020.

[27] L. Q. Liu and Z. X. Wang, "The development and application practice of wind-solar energy hybrid generation systems in China," Renewable and Sustainable Energy Reviews, vol. 13, no. 6-7, pp. 1504-1512, 2009.

[28] K. Pollack and J. C. Bongaerts, "Mathematical model on the integration of renewable energy in the mining industry," International Journal of Energy Sector Management, vol. 14, no. 1, pp. 229-247, 2020.

[29] Y.-M. Wei and H. Liao, Clean Energy Development and Energy Poverty, Emerald Publishing Limited, Bingley, UK, 2018.

[30] M. Jahangiri, F. Karimi Shahmarvandi, and R. Alayi, "Renewable energy-based systems on a residential scale in southern coastal areas of Iran: trigeneration of heat, power, and hydrogen," Journal of Renewable Energy and Environment, vol. 5, 2021.

[31] M. Jahangiri, A. Khosravi, H. A. Raiesi, and A. Mostafaeipour, "Analysis of standalone PV-based hybrid systems for power generation in Rural area," in Proceedings of the International Conference on Fundamental Research in Electrical Engineering, Tehran, Iran, 2017, https://en.civilica.com/doc/672922.

[32] J. Zaniani, R. Dehkordi, A. Bibak, P. Baya, and M. Jahangiri, "Examining the possibility of using solar energy to provide warm water using Retscreen4 software (case study: nasr primary school of pirbalut)," Current World Environment, vol. 10, pp. 835-841, 2015.

[33] M. Jahangiri, A. A. Shamsabadi, R. Riahi, F. Raeiszadeh, and P. F. Dehkordi, "Levelized cost of electricity for wind-solar power systems in Japan, a review," Journal of Power
Technologies, vol. 100, no. 3, pp. 188-210, 2020, https://papers. itc.pw.edu.pl/index.php/JPT/article/view/1359.

[34] A. Mostafaeipour, M. Rezaei, M. Jahangiri, and M. Qolipour, "Feasibility analysis of a new tree-shaped wind turbine for urban application: a case study," Energy \& Environment, vol. 31, no. 7, pp. 1230-1256, 2020.

[35] S. Pahlavan, M. Jahangiri, A. Alidadi Shamsabadi, and A. Rahimi Ariae, "Assessment of PV-Based CHP system: the effect of heat recovery factor and fuel type," Journal of Energy Management and Technology, vol. 3, no. 1, pp. 40-47, 2019.

[36] M. Jahangiri, O. Nematollahi, A. Haghani, H. A. Raiesi, and A. Alidadi Shamsabadi, "An optimization of energy cost of clean hybrid solar-wind power plants in Iran," International Journal of Green Energy, vol. 16, no. 15, pp. 1422-1435, 2019.

[37] M. Moein, S. Pahlavan, M. Jahangiri, and A. Alidadi Shamsabadi, "Finding the minimum distance from the national electricity grid for the cost-effective use of diesel generatorbased hybrid renewable systems in Iran," Journal of Renewable Energy and Environment, vol. 5, no. 1, pp. 8-22, 2018.

[38] A. Rahimi Ariae, M. Jahangiri, M. Haghgo Fakhr, and A. Alidadi Shamsabadi, "Simulation of biogas utilization effect on the economic efficiency and greenhouse gas emission: a case study in isfahan, Iran," International Journal of Renewable Energy Development, vol. 8, no. 2, pp. 149-160, 2019. 